ORIGINAL ARTICLE

\title{
Effect of hyperbaric oxygen on oxygen uptake and measurements in the blood and tissues in a normobaric environment
}

\author{
A N H Hodges, S Delaney, J M Lecomte, V J Lacroix, D L Montgomery
}

Br J Sports Med 2003;37:516-520

See end of article for authors' affiliations

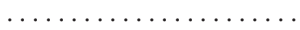

Correspondence to: Professor Montgomery, Kinesiology and Physical

Education, McGill

University, 475 Pine

Avenue West, Montreal

$\mathrm{H} 2 \mathrm{~W}$ 1S4, Canada;

David.Montgomery@mcgi-

Il.ca

Accepted

5 November 2002

\begin{abstract}
Objective: To examine venous partial pressure of oxygen $\left(\mathrm{PvO}_{2}\right)$, transcutaneous oxygen tension $\left.(\mathrm{tcPO})_{2}\right)$, and $\mathrm{VO}_{2} \mathrm{MAX}$ in a normobaric environment after a single hyperbaric oxygen $\left(\mathrm{HBO}_{2}\right)$ treatment.

Methods: This was a prospective study of conditions after the intervention compared with baseline. The participants were 10 moderately trained $\left(\mathrm{VO}_{2} \mathrm{MAX}=57.6 \mathrm{ml} / \mathrm{kg} / \mathrm{min}\right)$ men. Two $\mathrm{HBO}_{2}$ treatments consisting of breathing $95 \%$ oxygen at 2.5 atmospheres absolute (ATA) for 90 minutes were administered on non-consecutive days. Baseline testing included measures of $\mathrm{VO}_{2} \mathrm{MAX}, \mathrm{tcPO}_{2}$, and anthropometry. At 6.0 (1.0) minutes after the first $\mathrm{HBO}_{2}$ treatment, a $\mathrm{VO}_{2} \mathrm{MAX}$ test was performed. After the second $\mathrm{HBO}_{2}$ treatment, leg and chest tc $\mathrm{PO}_{2}$ and $\mathrm{PvO}_{2}$ were monitored for 60 minutes.

Results: $\mathrm{VO}_{2} \mathrm{MAX}$, running time, and peak blood lactate were not altered after the $\mathrm{HBO}_{2}$ treatment. Leg $t c \mathrm{PO}_{2}$ was lower $(\mathrm{p}=0.003)$ and chest $t \mathrm{PO} \mathrm{O}_{2}$ was unchanged after the $\mathrm{HBO}_{2}$ treatment compared with baseline values. $\mathrm{PrO}_{2}$ was significantly $(p<0.001)$ lower in the first three minutes after treatment than subsequent values, but no other differences were found.

Conclusions: $\mathrm{A}$ single $\mathrm{HBO}_{2}$ treatment at 2.5 ATA for 90 minutes does not raise $\mathrm{PvO}_{2}, \mathrm{tcPO}_{2}$, or $\mathrm{VO}_{2} \mathrm{MAX}$ in a normobaric, normoxic environment.
\end{abstract}

1 $\mathrm{n}$ recent years some professional and college athletic teams have used hyperbaric oxygen $\left(\mathrm{HBO}_{2}\right)$ to treat sports injuries, to speed recovery after exercise, and as an ergogenic aid to enhance performance. Because of the importance of oxygen in the aerobic energy system, professional athletes sometimes receive $\mathrm{HBO}_{2}$ before participation in their sport in the belief that subsequent performance will be improved. ${ }^{1} \mathrm{HBO}_{2}$ therapy is defined as a medical treatment in which the patient breathes $100 \%$ oxygen intermittently while inside a chamber at a pressure greater than 1 atmosphere absolute (ATA). ${ }^{2}$ The Undersea and Hyperbaric Medical Society currently approves 13 medical indications for treatment with $\mathrm{HBO}_{2}{ }^{2}$

Physiologists have long debated whether oxygen delivery or use by the skeletal muscles is the limiting factor for $\mathrm{VO}_{2} \mathrm{MAX}$. Potential physiological factors limiting $\mathrm{VO}_{2} \mathrm{MAX}$ include: (a) pulmonary diffusion capacity for $\mathrm{O}_{2} ;(b)$ maximal cardiac output; $(c)$ the peripheral circulation; (d) the metabolic capacity of skeletal muscle. ${ }^{3}$ According to Rowell, ${ }^{3}$ most physiologists believe that the capacity of the central cardiovascular system to transport oxygen to the tissues is the principal determinant of $\mathrm{VO}_{2} \mathrm{MAX}$. This concept has been used to justify $\mathrm{HBO}_{2}$ treatments to enhance the availability of oxygen in an attempt to increase maximal aerobic performance. Also, oxygen stored in the tissues after an $\mathrm{HBO}_{2}$ treatment may be available to working muscles.

Our reasons for this study are the contrary findings in the research literature ${ }^{4-7}$ and the observation that the athletic community has used $\mathrm{HBO}_{2}$ before sport performance. Under pressure, oxygen dissolves in all body fluids. ${ }^{8}$ For $\mathrm{HBO}_{2}$ to be beneficial, increased oxygen must be stored during the treatment and remain raised on return to a normobaric, normoxic environment. Previous studies have not examined the blood or tissues to determine if these compartments would be additional sources of oxygen available to the mitochondria during maximal exercise. Because of potential misuse by the athletic community, there is a need to establish if there are benefits in using $\mathrm{HBO}_{2}$ as an ergogenic aid. This study examines the ergogenic potential of $\mathrm{HBO}_{2}$. We hypothesised that: (a) venous partial pressure of oxygen $\left(\mathrm{PvO}_{2}\right)$ and/or transcutaneous oxygen tension $\left(\mathrm{tcPO}_{2}\right)$ would be unchanged after a single $\mathrm{HBO}_{2}$ treatment in a normobaric environment; $(b) \mathrm{VO}_{2} \mathrm{MAX}$ would be similar after a single $\mathrm{HBO}_{2}$ treatment in a normobaric environment.

\section{METHODS \\ Subjects}

The subjects were 10 trained $\left(\mathrm{VO}_{2} \mathrm{MAX}=57.6(6.2) \mathrm{ml} / \mathrm{kg} /\right.$ min) male volunteers (table 1 ). They were examined by a doctor and were excluded if contraindications to $\mathrm{HBO}_{2}$ treatment were evident (recent thoracic surgery, repeated ear infections, asthma, cataracts, diabetes, receiving anticonvulsant medication, hereditary spherocytosis, and recent upper respiratory tract infections). All experimental procedures were evaluated and approved by the McGill University Faculty of Medicine institutional review board. Subjects gave written consent to participate after the design and risks of the study had been described to them.

\section{Experimental design}

Subjects underwent tests on three non-consecutive days within a two week period. Baseline testing on day 1 included assessment of physical characteristics, $\mathrm{tc} \mathrm{PO}_{2}$ during normoxic and hyperoxic breathing, and measurement of $\mathrm{VO}_{2} \mathrm{MAX}$. Testing on day 2 included a 90 minute $\mathrm{HBO}_{2}$ treatment followed by a $\mathrm{VO}_{2} \mathrm{MAx}$ test. The time delay from exiting the hyperbaric chamber to the start of the $\mathrm{VO}_{2} \mathrm{MAX}$ test was 6.0 (1.0) minutes. On day 3, subjects received a 90 minute $\mathrm{HBO}_{2}$

Abbreviations: $\mathrm{HBO} 2$, hyperbaric oxygen; Pvo2, venous partial pressure of oxygen; tcPo2, transcutaneous oxygen tension; Vo2max, maximum oxygen consumption 


\begin{tabular}{lll|}
\hline $\begin{array}{l}\text { Table } 1 \\
(\mathrm{n}=10)\end{array}$ & Physical characteristics of the subjects \\
\hline Variable & Mean (SD) & Range \\
\hline Age (years) & $25.7(5.5)$ & $20-38$ \\
Height $(\mathrm{cm})$ & $179.7(7.5)$ & $165.0-194.9$ \\
Weight $(\mathrm{kg})$ & $76.4(4.1)$ & $70.9-82.3$ \\
Percentage fat & $10.2(2.0)$ & $5.5-17.4$ \\
Vo ${ }_{2} \mathrm{MAX}(\mathrm{ml} / \mathrm{kg} / \mathrm{min})$ & $57.6(6.2)$ & $47.5-67.1$ \\
\hline
\end{tabular}

treatment followed by nine $\mathrm{PvO}_{2}$ samples and $\mathrm{tcPO}_{2}$ measurements for 60 minutes.

\section{Hyperbaric oxygen protocol}

Figures 1 and 2 illustrate the $\mathrm{HBO}_{2}$ chamber and protocol. The $\mathrm{HBO}_{2}$ treatment was administered in a Sigma Plus monoplace hyperbaric chamber (Perry Baromedical Corporation, Riviera, Florida, USA) under the supervision of a certified chamber operator at the Cleghorn Hyperbaric Laboratory, McGill University. It took about 10 minutes to pressurise the chamber to 2.5 ATA with $95 \%$ oxygen. At 25 and 55 minutes into the 90 minute treatment, subjects were given a five minute air break through an oronasal mask to reduce the risk of oxygen toxicity. After 90 minutes, the chamber was decompressed from 2.5 to 1.0 ATA in about eight minutes.

Under normal sea level conditions, barometric pressure is 1 ATA or $760 \mathrm{~mm} \mathrm{Hg}$, and oxygen content in the air is $20.9 \%$. In these conditions the $\mathrm{PaO}_{2}$ is $100 \mathrm{~mm} \mathrm{Hg}$. During our $\mathrm{HBO}_{2}$ treatment, the combination of increased pressure (2.5 ATA) and increased oxygen concentration $(95 \%)$ results in additional oxygen dissolved in plasma. During the hyperbaric treatment at these conditions the $\mathrm{PaO}_{2}$ is predicted to be:

$\mathrm{PaO}_{2}=\left(\left(\mathrm{PBTPS} \times \mathrm{FIO}_{2}\right)-\left(\mathrm{PaCO}_{2} / \mathrm{R}\right)\right)$

$\mathrm{PaO}_{2}=(((2.5$ ATA $\times 760)-47 \mathrm{~mm} \mathrm{Hg}) \times 0.95)-$ $(40 \mathrm{~mm} \mathrm{Hg} / 0.82)$

$\mathrm{PaO}_{2}=1853-49=1804 \mathrm{~mm} \mathrm{Hg}$

where PBTPS $=$ pressure at body temperature pressure saturated $(\mathrm{mm} \mathrm{Hg}), \mathrm{FIO}_{2}=$ fraction of oxygen in inspired air $(\%), \mathrm{PaCO}_{2}=$ partial pressure of $\mathrm{CO}_{2}$ in arterial blood $(\mathrm{mm} \mathrm{Hg})$, and $\mathrm{R}=$ respiratory quotient.

\section{Exercise test procedure}

Before the exercise test, physical characteristics (height, weight, and body composition) were measured. Percentage body fat was estimated from skinfold measurements and the regression equation of Jackson and Pollock. ${ }^{9}$

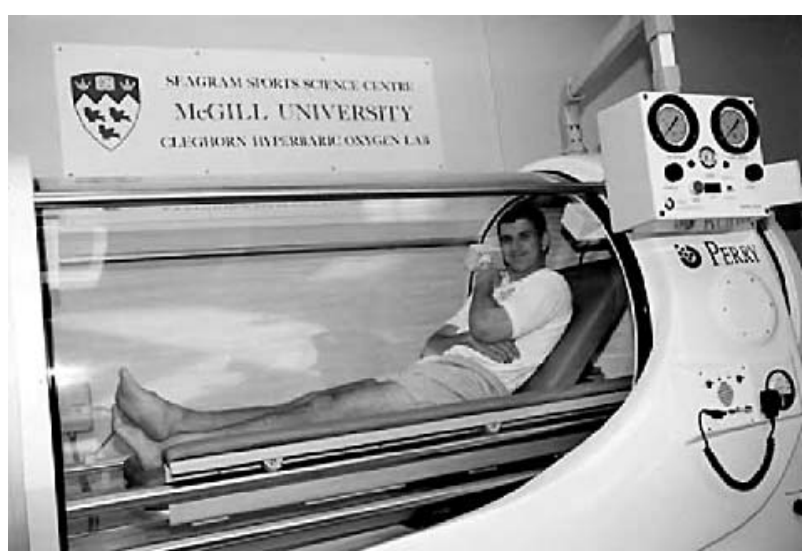

Figure 1 Hyperbaric oxygen monoplace chamber.

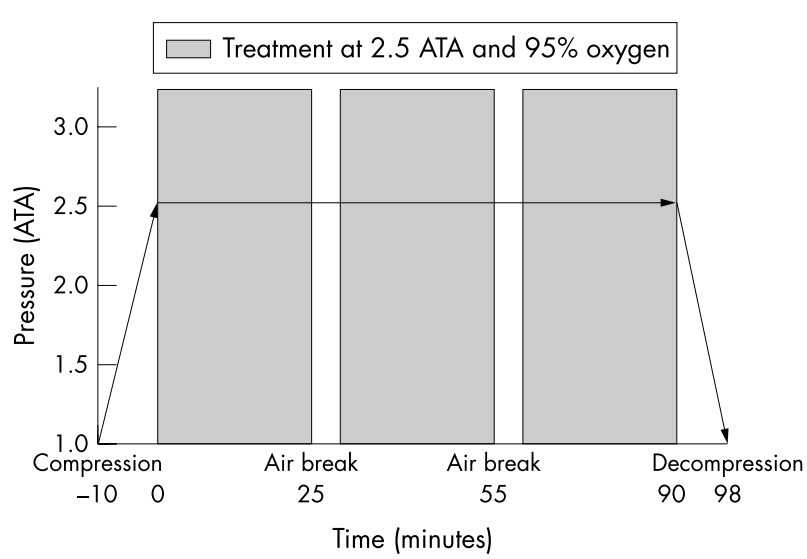

Figure 2 Hyperbaric oxygen protocol. ATA, Atmospheres absolute.

$\mathrm{VO}_{2} \mathrm{MAX}$ was measured on a Quinton Q65 Series 90 treadmill (Quinton Instruments, Seattle, Washington, USA). Subjects began an incremental test at $5 \mathrm{mph}(134 \mathrm{~m} /$ min) and $5 \%$ grade with speed increased by $0.5 \mathrm{mph}(13.4 \mathrm{~m} /$ $\mathrm{min}$ ) every minute until volitional exhaustion. Expired gases were collected with $\mathrm{VE}, \mathrm{VO}_{2}$, and $\mathrm{VCO}_{2}$ averaged every 20 seconds using a SensorMedics 2900 Metabolic Measurement Cart (SensorMedics, Yorba Linda, California, USA). Subjects were verbally encouraged to continue exercising until volitional exhaustion. Criteria for reaching $\mathrm{VO}_{2} \mathrm{MAX}$ were attainment of age predicted heart rate maximum, a respiratory exchange ratio of 1.10 , or a plateau in $\mathrm{VO}_{2}$ with increased workload. $\mathrm{VO}_{2} \mathrm{MAX}$ was calculated by averaging the highest values over one minute. Heart rate was measured using a Polar Accurex Heart Rate Monitor (Polar Electro, Kempele, Finland) and averaged every five seconds. Four minutes after the $\mathrm{VO}_{2} \mathrm{MAX}$ test, a finger prick blood sample was taken to determine peak blood lactate concentration. The blood samples were analysed with an Accusport Portable Lactate Analyzer (Behringer Mannheim, Mannheim, Germany).

\section{tcPO $\mathrm{P}_{2}$ measurement}

$\mathrm{tcPO}_{2}$ was measured at two sites: chest (second intracostal) and leg (mid-thigh over the rectus femoris). The sites were prepared by removal of hair, cleaning with alcohol, and denuding the skin by repeated application and removal of adhesive tape. ${ }^{10}$ A calibrated TCM 30 Transcutaneous $\mathrm{PO}_{2}$ Monitoring System (Radiometer, Copenhagen, Denmark) was used to measure $\mathrm{tcPO}_{2}$ continuously. The electrodes were warmed to $45 \mathrm{C}$ as recommended for use in hyperbaric operations. ${ }^{11}{ }^{12}$ There was a lag of about 10 minutes after application of the electrodes before stable values were achieved. Values were recorded every minute for 60 minutes. The baseline $\mathrm{tcPO}_{2}$ assessment included a 20 minute oxygen challenge in which the subjects breathed $100 \%$ oxygen through an oronasal mask from minute 20 to minute 40 to demonstrate their $\mathrm{tcPO}_{2}$ responsiveness to high concentrations of oxygen.

\section{$\mathrm{PvO}_{2}$ measurement}

When each subject left the hyperbaric chamber on day 3, a 14 gauge intravenous catheter was inserted into an antecubital vein. The line was kept patent between samples with 5\% dextrose solution (IVD5W). Blood samples (3-5 ml) were drawn $3,5,10,15,20,30,40,50$, and 60 minutes after the subject had left the chamber. To ensure blood samples were not contaminated with IVD5W solution, $5 \mathrm{ml}$ blood was drawn and discarded before every blood sample was collected. Samples were immediately aspirated into a 
Radiometer ABL5 blood analyser, which was calibrated with known samples provided by the manufacturer. Every 30 minutes, the blood analyser performed a barometric pressure and a $\mathrm{l}$ point calibration of the $\mathrm{PO}_{2}$ electrode using gas of $19.8 \% \mathrm{O}_{2}$. Every two hours the blood analyser performed a 2 point calibration of the $\mathrm{PO}_{2}$ electrode using gases of $0 \%$ and $19.8 \% \mathrm{O}_{2}$.

With regard to blood sampling, our preference was to obtain arterial $\mathrm{PO}_{2}\left(\mathrm{PaO}_{2}\right)$ measurements because it is unclear how long $\mathrm{PaO}_{2}$ remains raised after an $\mathrm{HBO}_{2}$ treatment. The ethics institutional review board did not approve arterial sampling for this study, and requested that an intravenous catheter be used to obtain blood samples.

\section{Statistical analysis}

Paired $t$ tests were used to compare baseline conditions with those after treatment for $\mathrm{VO}_{2} \mathrm{MAX}$ and peak blood lactate data. A one way repeated measures analysis of variance was used to compare $\mathrm{PvO}_{2}$ data for the two conditions. A two way repeated measures analysis of variance was used to compare tcPO $\mathrm{P}_{2}$ data at two sites (chest and leg) and two conditions (baseline and after $\mathrm{HBO}_{2}$ ). Analysis of variance was followed by post hoc comparisons using Tukey's HSD (honestly significant difference) test. For all statistical analyses, was set at $\mathrm{p}<0.05$.

\section{RESULTS}

Table 2 shows the exercise test results. No significant differences were found for $\mathrm{VO}_{2} \mathrm{MAX}$ or peak blood lactate concentration between the baseline condition and after $\mathrm{HBO}_{2}$ treatment. The mean (SD) $\mathrm{Vo}_{2} \mathrm{MAX}$ values were 57.6 (6.2) and $57.3(5.8) \mathrm{ml} / \mathrm{kg} / \mathrm{min}$ in the two conditions. The time from exiting the chamber and initiation of the exercise test was 6.0 (1.0) minute. The $\mathrm{HBO}_{2}$ treatment did not enhance exercise performance, as run times were identical in both conditions (10.1 (1.9) min). Peak lactate concentrations were similar (8.9 (2.8) and 10.0 (1.9) $\mathrm{mmol} / \mathrm{l})$ in the two conditions.

Table 3 summarises and fig 3 illustrates the $\mathrm{PvO}_{2}$ results. There was a significant change in $\mathrm{PvO}_{2}$ over time $(F=6.61$; df 8.40; $\mathrm{p}<0.001$ ) after the $\mathrm{HBO}_{2}$ treatment, with a lower $\mathrm{PO}_{2}$ value at three minutes than at 5-60 minutes. The tourniquet on the upper arm was in place for about one minute before drawing of the initial blood sample. We attribute the significantly lower $\mathrm{PO}_{2}$ at three minutes to altered blood flow in the arm. The $\mathrm{PvO}_{2}$ data suggest that there was no excess oxygen circulating in the blood after the $\mathrm{HBO}_{2}$ treatment.

Figure 4 summarises the $\mathrm{tcPO}_{2}$ data. In the baseline condition, the start of the oxygen challenge was at 20 minutes. The chest $\mathrm{tcPO}_{2}$ increased from about 80 to $290 \mathrm{~mm} \mathrm{Hg}$ in about five minutes, and the leg $\mathrm{tcPO}_{2}$ increased from 70 to $230 \mathrm{~mm} \mathrm{Hg}$ in the same time frame. Upon completion of the oxygen challenge at 40 minutes, both the chest and leg $\mathrm{tcPO}_{2}$ returned to baseline values within three minutes. After the $\mathrm{HBO}_{2}$ treatment, the leg $\mathrm{tcPO} \mathrm{P}_{2}$ was

Table 2 Physiological responses during exercise tests

\begin{tabular}{lll}
\hline Variable & Baseline & After $\mathrm{HBO}_{2}$ \\
\hline $\mathrm{VO}_{2} \mathrm{MAX}(\mathrm{ml} / \mathrm{kg} / \mathrm{min})$ & $57.6(6.2)$ & $57.3(5.8)$ \\
$\mathrm{VO}_{2} \mathrm{MAX}$ (litre/min) & $4.38(0.5)$ & $4.38(0.5)$ \\
Run time (min) & $10.1(1.9)$ & $10.1(1.9)$ \\
HRMAX (beats/min) & $191(10.3)$ & $189(11.3)$ \\
LaMAX (mmol/l) & $8.9(2.8)$ & $10.0(1.9)$ \\
\hline
\end{tabular}

Values are mean (SD)

$\mathrm{VO}_{2} \mathrm{MAX}$, Maximum oxygen consumption; HRMAX, maximum heart rate; LaMAX, maximum blood lactate concentration.

\begin{tabular}{|ll|}
\hline $\begin{array}{l}\text { Table } 3 \\
\text { treatment }\end{array}$ & Venous $\mathrm{PO}_{2}$ after hyperbaric \\
\hline Time (min) & $\mathrm{Po}_{2}(\mathrm{~mm} \mathrm{Hg})$ \\
\hline 3 & $18.0(4.3)^{*}$ \\
5 & $31.3(7.9)$ \\
10 & $37.1(10.6)$ \\
15 & $36.3(6.8)$ \\
20 & $37.3(9.1)$ \\
30 & $37.0(10.2)$ \\
40 & $36.8(9.6)$ \\
50 & $38.7(15.6)$ \\
60 & $31.7(9.4)$ \\
\hline Values are mean (SD). & \\
*Significantly different from other readings $(\mathrm{p}<0.001)$. \\
\hline
\end{tabular}

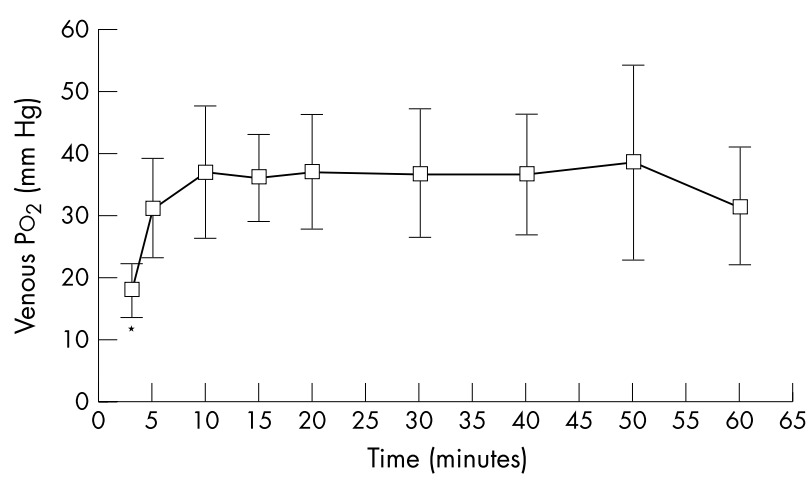

Figure 3 Venous $\mathrm{PO}_{2}$ plotted against time after hyperbaric treatment. ${ }^{*} p<0.001$ compared with all other values.

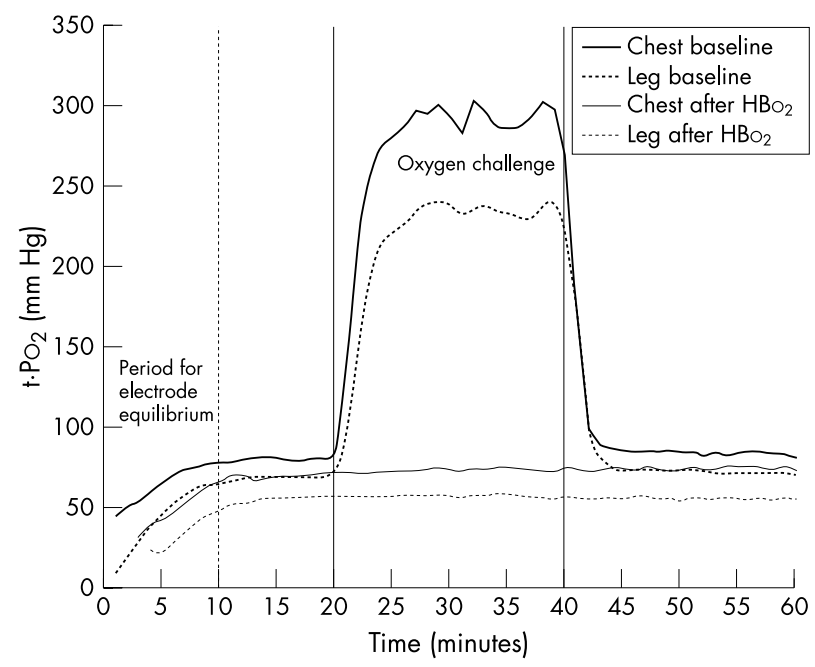

Figure 4 Chest and leg transcutaneous oxygen tension $\left(t c \mathrm{PO}_{2}\right)$ during the baseline and hyperbaric treatment $\left(\mathrm{HBO}_{2}\right)$ conditions versus time.

significantly $(F=11.93 ; \mathrm{df} 1.18 ; \mathrm{p}=0.003)$ lower than the baseline values, with a difference of $14 \mathrm{~mm} \mathrm{Hg}$. In contrast, the chest $\mathrm{tCPO}_{2}$ values were similar at baseline and after $\mathrm{HBO}_{2}$ treatment.

\section{DISCUSSION}

Intermittent $\mathrm{HBO}_{2}$ treatments have been used to speed recovery of muscle strength after exercise induced injury. Quadriceps muscle soreness was induced by eccentric exercise. ${ }^{13} \mathrm{HBO}_{2}$ treatments improved recovery of eccentric strength compared with placebo treatments. The effect of a 
single $\mathrm{HBO}_{2}$ treatment on subsequent exercise performance has also been examined. Kaijser ${ }^{14}$ compared dynamic forearm exercise under hyperbaric (3.0 ATA) and normobaric conditions. The performance time to exhaustion was increased in three subjects and unchanged in three subjects.

There is evidence that breathing hyperoxic gas during exercise enhances performance. ${ }^{15-21}$ Using arterial and femoral venous sampling combined with measurement of blood flow, it has been shown that hyperoxia increases $\mathrm{VO}_{2}$ MAX of an exercising leg. ${ }^{18}$ As it is unclear if $\mathrm{HBO}_{2}$ treatment before exercise alters performance, we examined $\mathrm{PVO}_{2}, \mathrm{tcPO}_{2}$, and $\mathrm{VO}_{2} \mathrm{MAX}$ in a normobaric environment after a single $\mathrm{HBO}_{2}$ treatment.

Four studies have investigated maximal aerobic performance in a normobaric environment after $\mathrm{HBO}_{2}$ treatments, with two studies showing positive findings ${ }^{5}{ }^{6}$ and two studies reporting no benefits. ${ }^{4}{ }^{7}$

Cabric et $a l^{6}$ administered $100 \%$ oxygen at 2.8 ATA for 60 minutes. Eighteen female students were randomly divided into three groups (six per group). After the $\mathrm{HBO}_{2}$ treatment, the first group performed a $\mathrm{VO}_{2} \mathrm{MAX}$ test at 30 minutes, the second at three hours, and the third at six hours. Both $\mathrm{VO}_{2} \mathrm{MAX}$ and treadmill run time to exhaustion had increased significantly 30 minutes and three hours after treatment. After the $\mathrm{HBO}_{2}$ treatment, $\mathrm{VO}_{2} \mathrm{MAX}$ had increased by $15 \%$ at 30 minutes $(p<0.05), 10 \%$ at three hours $(p<0.05)$, and $7 \%$ at six hours (non-significant). The improved performance was attributed to oxygen stored within skeletal muscle tissue. It has also been reported that blood lactate levels, $\mathrm{Vo}_{2}$, and $\mathrm{VCO}_{2}$ were lower during submaximal exercise in a normobaric environment after $\mathrm{HBO}_{2} \cdot{ }^{14}$ This study included only two subjects and therefore it is difficult to generalise their findings.

Webster et al questioned the ergogenic effect of $\mathrm{HBO}_{2}$. Their subjects performed three exercise tests on a cycle ergometer. These tests were performed on separate days with the first two exercise tests designed to establish baseline data, and the third test after an $\mathrm{HBO}_{2}$ treatment at 2.0 ATA for 60 minutes. The mean time from exiting the chamber to cycling was 22.5 minutes. No significant differences were found for $\mathrm{VO}_{2} \mathrm{MAX}$, ventilatory threshold, lactate threshold, VEMAX, or HRMAX for the three tests. Near infrared spectroscopy was used to examine tissue oxygenation of the vastus lateralis muscle at rest, throughout exercise, and during recovery. After the $\mathrm{HBO}_{2}$ treatment, muscle tissue oxygenation during rest and recovery were similar to control values.

McGavock et al ${ }^{4}$ examined the acute effects of a single $\mathrm{HBO}_{2}$ treatment on aerobic performance in a normobaric environment. Subjects $(\mathrm{n}=12)$ performed four exercise- $\mathrm{HBO}_{2}$ conditions designated as: (a) control; $(b)$ exercise-non- $\mathrm{HBO}_{2}$; (c) no exercise- $\mathrm{HBO}_{2} ;$ (d) exercise- $\mathrm{HBO}_{2}$. Exercise was a 90 minute run to produce fatigue. The $\mathrm{HBO}_{2}$ treatments were at 2.5 ATA for 90 minutes. At the end of each condition, aerobic performance was assessed using running economy tests and a $\mathrm{VO}_{2} \mathrm{MAX}$ test. The time between exiting the chamber and running on the treadmill averaged 40 minutes. Recovery was not enhanced after a single $\mathrm{HBO}_{2}$ treatment nor did it alter submaximal or maximal running performance.

Our findings support the results of Webster et $a l^{7}$ and McGavock et al. ${ }^{4}$ Baseline conditions and those after $\mathrm{HBO}_{2}$ were similar for $\mathrm{VO}_{2} \mathrm{MAX}$, treadmill running time, and peak blood lactate, indicating that the single $\mathrm{HBO}_{2}$ treatment was not ergogenic.

$\mathrm{tcPO}_{2}$ is a reliable assessment of oxygen available to tissues. ${ }^{10}$ It is traditionally used to predict if $\mathrm{HBO}_{2}$ treatment will be beneficial for wound healing and to maintain tissue oxygen values within an appropriate range. ${ }^{22}$ Chest $\mathrm{tcPO}_{2}$ values have been recorded at 1312 (112) mm Hg during a $\mathrm{HBO}_{2}$ treatment at $2.4 \mathrm{ATA}^{23}$ In our study, $\mathrm{tcPO}_{2}$ was used to
Take home message

A single $\mathrm{HBO}_{2}$ treatment at 2.5 ATA for 90 minutes does not raise $\mathrm{VO}_{2} \mathrm{max}$ in a normobaric, normoxic environment. Transcutaneous tissue and blood $\mathrm{PO}_{2}$ measurements after the $\mathrm{HBO}_{2}$ treatment support the statement that $\mathrm{HBO}_{2}$ does not have ergogenic benefits for the athletic community.

assess oxygen levels in muscle tissue after the $\mathrm{HBO}_{2}$ treatment. It appears that the excess oxygen that is physically dissolved in plasma during $\mathrm{HBO}_{2}$ is rapidly consumed upon exiting the $\mathrm{HBO}_{2}$ chamber. Upon application of the $\mathrm{tcPO}_{2}$ electrode, it takes about 10 minutes to obtain a reliable value as the electrode warms the skin. ${ }^{10}$ In our study, 10 minutes after exiting the chamber $\mathrm{tcPO}_{2}$ values had returned to baseline and leg $\mathrm{tcPO}_{2}$ values were lower than baseline. The lower $\mathrm{tcPO}_{2}$ values in the leg may be attributed to vasoconstriction. It has been shown both in vivo and in vitro that blood flow is decreased when inspired $\mathrm{PO}_{2}$ increases above $500 \mathrm{~mm} \mathrm{Hg.}{ }^{24}$ The vasoconstrictive effect occurs in both arterial and venous vascular beds. ${ }^{25}$

Sheffield ${ }^{10}$ presents normal values for blood and tissue $\mathrm{O}_{2}$ measured by blood gas analyser, mass spectrometer, tissue tonometer, implanted polarographic electrode, and $\mathrm{tcPO}_{2}$ at pressures of 1-3 ??ATA. Normal mean values for $\mathrm{PvO}_{2}$ range from 36 to $40 \mathrm{~mm} \mathrm{Hg.}{ }^{26}$ Between 10 and 60 minutes after $\mathrm{HBO}_{2}$, our $\mathrm{PvO}_{2}$ data ranged from 31.7 to $38.7 \mathrm{~mm} \mathrm{Hg}$ indicating that there was no excess oxygen circulating in the blood. Banister et al examined $\mathrm{PaO}_{2}$ and $\mathrm{PaCO}_{2}$ after an $\mathrm{HBO}_{2}$ treatment in two subjects. The $\mathrm{PaO}_{2}$ and $\mathrm{PaCO}_{2}$ remained unchanged. The time from the end of treatment to drawing blood samples was not stated. Our $\mathrm{PvO}_{2}$ and $t \mathrm{tCO}_{2}$ data indicate that plasma and tissue oxygen levels are not raised after $\mathrm{HBO}_{2}$. After our $\mathrm{HBO}_{2}$ treatment, $\mathrm{PvO}_{2}$ was relatively constant from 5 to 60 minutes. The only significant finding occurred at three minutes after treatment with a lower $\mathrm{PvO}_{2}$ value. We attribute the significantly lower $\mathrm{Po}_{2}$ at three minutes to altered blood flow in the arm, as a tourniquet was placed on the upper arm for about one minute before drawing of the initial blood sample. The $\mathrm{PvO}_{2}$ data suggest that there was no excess oxygen circulating in the blood after the $\mathrm{HBO}_{2}$ treatment. Tissue autoregulation reduces $\mathrm{O}_{2}$ levels upon return to a normobaric, normoxic environment. ${ }^{28}$

In summary, the results of this study show that a single $\mathrm{HBO}_{2}$ treatment at 2.5 ATA for 90 minutes does not raise $\mathrm{VO}_{2} \mathrm{MAX}$ in a normobaric, normoxic environment. Oxygen measurements in the venous blood $\left(\mathrm{PvO}_{2}\right)$ and in the tissues $\left(\mathrm{tcPO}_{2}\right)$ provide new data to support the rationale that $\mathrm{HBO}_{2}$ treatments do not enhance performance. This message needs to be conveyed by doctors and sport scientists to the athletic community. Our findings support the work of Webster et al, McGavock et al, ${ }^{4}$ and the Undersea and Hyperbaric Medical Society statement that $\mathrm{HBO}_{2}$ does not have ergogenic properties.

\section{Authors' affiliations}

A N H Hodges, J S Delaney, J M Lecomte, V J Lacroix, D L Montgomery, McGill University, Montreal, Canada

\section{REFERENCES}

1 Potera C. Healing under pressure. Physician and Sports Medicine 1995;23:46-7.

2 Hampson NB, e, eds. Hyperbaric oxygen therapy: 1999 committee report. Kensington, MD: Undersea \& Hyperbaric Medical Society, 1999.

3 Rowell LB. Human circulation: regulation during physical stress. New York Oxford University Press, 1986:243-6. 
4 McGavock JM, Lecomte JL, Delaney JS, et al. Effects of hyperbaric oxygen on aerobic performance in a normobaric environment. Undersea Hyperb Med 1999;26:219-24.

5 Banister EW, Taunton JE, Patrick T, et al. Effect of oxygen at high pressure at rest and during severe exercise. Respir Physiol 1970;10:74-84.

6 Cabric M, Medved R, Denoble P, et al. Effect of hyperbaric oxygenation on maximal aerobic performance in a normobaric environment. $J$ Sports Med Phys Fitness 1991;31:362-6.

7 Webster AL, Syrotuik DG, Bell GJ, et al. Exercise after acute hyperbaric oxygenation: is there an ergogenic effect? Undersea Hyperb Med 1998;25:153-9

8 Leach RM, Rees PJ, Wilmshurst, P. ABC of oxygen: hyperbaric oxygen therapy. BMJ 1998;317:1140-3.

9 Jackson AS, Pollock ML. Generalized equations for predicting body density of men. Br J Nutr 1978;40:497-504.

10 Sheffield PJ. Measuring tissue oxygen tension: a review. Undersea Hyperb Med 1998;25:179-88.

11 Huch A, Huch R, Hollmann G, et al. Transcutaneous $\mathrm{PO}_{2}$ of volunteers during hyperbaric oxygenation. Biotelemetry 1997;4:88-100.

12 Robertson PW, Hart BB. Assessment of tissue oxygenation. Respir Care Clin N Am 1999;5:221-63.

13 Staples JR, Clement DB, Taunton JE, et al. Effects of hyperbaric oxygen on a human model of injury. Am J Sports Med 1999;27:600-5.

14 Kaijser L. Physical exercise under hyperbaric oxygen pressure. Life Sci 1969;8:929-34.

15 Adams RP, Welch HG. Oxygen uptake, acid-base status, and performance with varied inspired oxygen fractions. J Appl Physiol 1980;49:863-8.

16 Cunningham DA. Effects of breathing high concentrations of oxygen on treadmill performance. Res Q 1966;37:491-4.
17 Ekblom B, Huot R, Stein EM, et al. Effect of changes in arterial oxygen content on circulation and physical performance. J Appl Physiol 1975;39:71-5.

18 Knight DR, Schaffartzik W, Poole DC, et al. Effects of hyperoxia on maximal leg $\mathrm{O}_{2}$ supply and utilization in men. J Appl Physiol 1993;75:2586-94.

19 Nielson $\mathrm{HB}$, Madsen $\mathrm{P}$, Svendsen $\mathrm{LB}$, et al. The influence of $\mathrm{P}_{0} \mathrm{O}_{2}, \mathrm{pH}$ and $\mathrm{S}_{\mathrm{a}} \mathrm{O}_{2}$ on maximal oxygen uptake. Acta Physiol Scand 1998;164:89-97.

20 Richardson RS, Grassi B, Gavin TP, et al. Evidence of $\mathrm{O}_{2}$ supply-dependent $\mathrm{VO}_{2} \mathrm{MAX}$ in the exercise-trained human quadriceps. J Appl Physiol 1999:86:1048-53.

21 Wilson GD, Welch HG. Effects of hyperoxic gas mixtures on exercise tolerance in man. Med Sci Sports 1975;7:48-52.

22 Van der Kleij AJ, Kooyman R, Bakker DJ. Clinical value of transcutaneous $\mathrm{PO}_{2}$ assessment during hyperbaric oxygen therapy. In: Nemoto EM, LaManna JC, eds. Oxygen transport to tissue XVIII. New York: Plenum Press, 1997:1 13-20.

23 Dooley J, King G, Slade B. Establishment of reference pressure of transcutaneous oxygen for the comparative evaluation of problem wounds. Undersea Hyperb Med 1997;24:235-44.

24 Plewes JL, Farhi LE. Peripheral circulatory responses to acute hyperoxia. Undersea Biomed Res 1983;10:123-9.

25 Fife CE, Camporesi EM. Physiologic effects of hyperbaric hyperoxia. Problems in Respiratory Care 1991;4:142-9.

26 Guyton AC, Hall JE. Textbook of medical physiology, 9th ed. Philadelphia: WB Saunders Company, 1996:513-23.

27 Wells $\mathrm{CH}$, Goodpasture JE, Horrigan DJ, et al. Tissue gas measurements during hyperbaric oxygen exposure. In: Smith G, e, eds. Proceedings of the Sixth International Congress on Hyperbaric Medicine. Aberdeen: Aberdeen University Press, 1977:118-24.

28 Kelly DL, Lassiter KR, Vongsvivut A, et al. Effects of hyperbaric oxygenation and tissue oxygen studies in experimental paraplegia. J Neurosurg 1972;36:425-9.

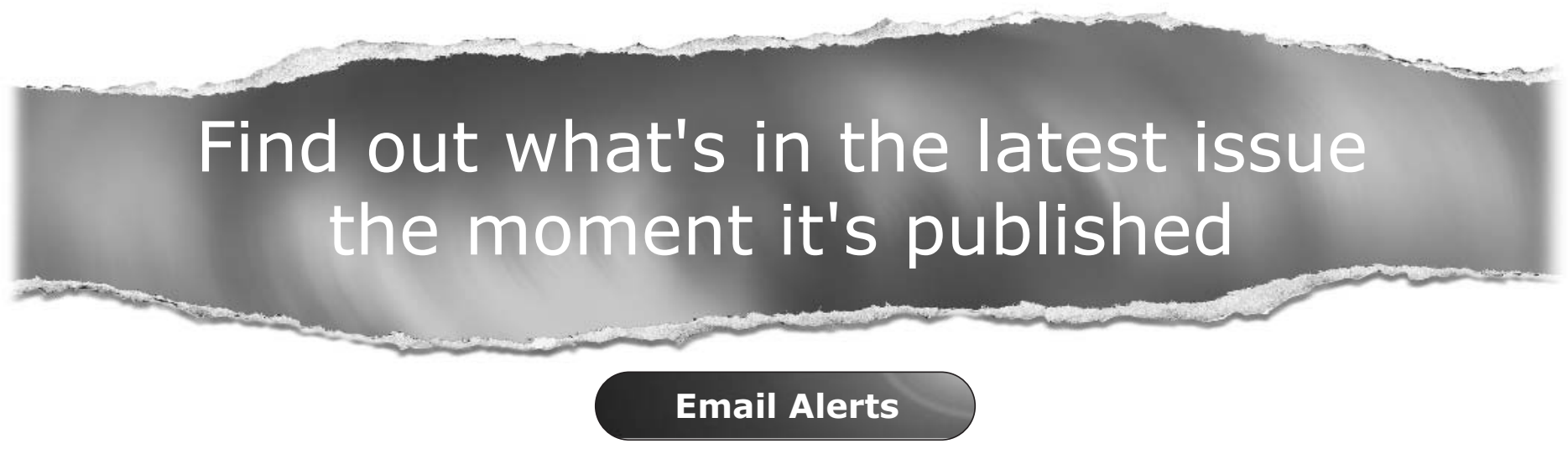

Sign up to receive the table of contents by email every month. You can select from three alerts:

Table of Contents (full), TOC Awareness (notice only); British Journal of Sports Medicine related announcements.

www.bjsportmed.com 